Vol.5 No.3

\title{
ANALISIS FAKTOR-FAKTOR YANG MEMPENGARUHI NIAT MEMBELI ONLINE PADA USAHA KECIL DAN MENENGAH DI MANADO (STUDI PADA MAHASISWA PERGURUAN TINGGI)
}

\section{Debry Ch. A. Lintong}

Universitas Sam Ratulangi

A R T ICLE INFO

Keywords: attitude, subjective norm, perceived behavioral control, online buying intention, small and medium enterprise, university students

Kata Kunci: lingkungan internal, lingkungan eksternal, keunggulan bersaing kinerja usaha.

Corresponding author: Debry Ch. A. Lintong debry_lintong@unsrat.ac.id
Abstract: The aim of the study was to determine the effect of attitudes, subjective norms, and perceived behavioral control simultaneously and partially on online buying intentions in SMEs in Manado. Research methods use quantitative research. The study was conducted at the Faculty of Economics and Business Unsrat Manado, in 2017. Samples were students with a total sample of 80 respondents. Data analysis uses multiple linear regression. The results of the study found that attitudes, subjective norms and perceived behavioral control simultaneously had a positive and significant influence on online buying intentions in SMEs in Manado. Furthermore, based on the results of hypothesis testing, it was found that partially the attitude, subjective norms and perceived behavioral control variables had a positive and significant influence on online buying intentions in SMEs in Manado. Attitude variables are the most dominant variables affecting online buying intention. Subjective norm variables are variables that have the least influence on online buying intentions compared to the other two variables. The variable perceived behavioral control is the second strongest variable that influences online buying intentions.

Abstrak: Tujuan penelitian untuk mengetahui pengaruh sikap, norma subjektif, dan perceived behavioral control secara simultan dan parsial terhadap niat membeli online pada UKM di Manado. Metode penelitian menggunakan penelitian kuantitatif. Penelitian dilakukan di Fakultas Ekonomi dan Bisnis Unsrat Manado, pada tahun 2017. Sampel adalah mahasiswa dengan jumlah sampel sebanyak 80 responden. Analisis data menggunakan regresi linear berganda. Hasil penelitian yaitu ditemukan bahwa sikap, norma subyektif serta perceived behavioral control secara simultan penelitian memiliki pengaruh positif dan signifikan terhadap niat membeli online pada UKM di Manado. Selanjutnya Berdasarkan hasil uji hipotesis ditemukan bahwa secara parsial variabel sikap, norma subjektif dan perceived behavioral control memiliki pengaruh positif dan signifikan terhadap niat membeli online pada UKM di Manado. Variabel sikap merupakan variabel yang paling dominan pengaruhnya terhadap niat membeli online. Variabel norma subjektif merupakan variabel yang paling kecil pengaruhnya terhadap niat membeli online dibandingkan dua variabel lainnya. Variabel perceived behavioral control merupakan variabel kedua terkuat yang berpengaruh terhadap niat membeli online. 


\section{Latar Belakang}

\section{PENDAHULUAN}

Potensi ekonomi digital lewat bisnis online memiliki peluang luar biasa untuk berkembang di Indonesia, khususnya di Manado. Dengan jumlah penduduk mencapai sekitar 262 juta jiwa, Indonesia dituntut untuk menjadi pelaku bisnis ekonomi digital di kancah dunia. Apalagi, data dari media online menyebutkan jumlah pengguna internet di Indonesia setiap tahun terus bertambah. Pada 2013, jumlah pengguna internet tercatat baru mencapai 72,8 juta, yang kemudian naik menjadi 102,8 juta di 2016. Di 2017, pengguna internet Indonesia diprediksi mencapai 112,6 juta (Liputan6.com, 2017).

Indonesia bahkan menjadi negara dengan pertumbuhan bisnis online tertinggi di dunia. Beberapa tahun terakhir, makin banyak pelaku usaha, baik perusahaan besar maupun ritel, beralih atau mengembangkan usaha ke arah digital. Data Sensus Ekonomi 2016 dari Badan Pusat Statistik (BPS) menyebutkan, industri e-Commerce atau bisnis online Indonesia dalam sepuluh tahun terakhir tumbuh sekitar tujuh belas persen dengan total jumlah bisnis online mencapai 26,2 juta unit (Liputan6.com, 2017).

Sementara itu, riset global dari Bloomberg menyatakan, pada 2020 lebih dari separuh penduduk Indonesia akan terlibat di aktivitas e-Commerce. McKinsey dalam laporan bertajuk 'Unlocking Indonesia's Digital Opportunity' juga menyebutkan, peralihan ke ranah digital akan meningkatkan pertumbuhan ekonomi hingga US\$ 150 miliar dolar pada 2025. Laporan itu menyatakan pula, 73 persen pengguna internet di Indonesia mengakses internet melalui perangkat selular. Angka ini diperkirakan akan terus bertambah dalam lima tahun ke depan (Liputan6.com, 2017).

Permasalahan yang dihadapi untuk bisnis online untuk UKM berbasis online khususnya di Manado adalah bagaimana memprediksi minat atau niat untuk membeli secara online pada para konsumen. Untuk itu penelitian ini dibuat untuk memprediksi niat membeli online dengan mencari beragam faktor yang bisa memprediksi niat membeli online. Niat membeli penting karena merupakan salah satu faktor tunggal terpenting dalam memprediksi perilaku khususnya perilaku pembelian secara online. Niat membeli online dalam penelitian ini diproksi dengan variabel-variabel dari Theory of Planned Behavior yang terdiri dari variabel sikap (attitude), norma subjektif (subjective norm), serta kontrol perilaku persepsian (perceived behavioral control). Penelitian dilakukan pada para mahasiswa dengan alasan bahwa mahasiswa merupakan agen perubahan yang menjadi pionir dan dianggap lebih memahami permasalahan karena mahasiswa juga merupakan generasi digital saat ini yang menjadi generasi masa depan sebagai konsumen dan juga pelaku usaha bisnis online.

\section{Tujuan Penelitian}

Tujuan penelitian ini adalah untuk menganalisis pengaruh:

1. Untuk mengetahui pengaruh sikap, norma subjektif, dan perceived behavioral control secara simultan terhadap niat membeli online pada UKM di Manado.

2. Untuk mengetahui pengaruh sikap, terhadap niat membeli online pada UKM di Manado.

3. Untuk mengetahui pengaruh norma subjektif terhadap niat membeli online pada UKM di Manado.

4. Untuk mengetahui pengaruh perceived behavioral control terhadap niat membeli online pada UKM di Manado.

\section{TINJAUAN PUSTAKA}

\section{Landasan Teori}

\section{Manajemen Pemasaran}

Manajemen pemasaran yaitu pengelolaan permintaan, serta pengelolaan hubungan dengan pelanggan. Manajemen pemasaran bukan hanya memperhatikan penemuan dan peningkatan permintaan, tetapi juga pengubahan bahkan pengurangan permintaan. Pengelolaan permintaan berarti mengelola pelanggan. (Kotler \& Armstrong, 2013). Definisi lainnya dari manjemen pemasaran sebagai seni dan ilmu memilih pasar sasaran dan mendapatkan, menjaga, dan menumbuhkan pelanggan dengan menciptakan, menyerahkan, dan mengomunikasikan nilai pelanggan yang unggul (Kotler \& Keller, 2009). 


\section{Theory of Planned Behavior}

Theory of planned Behavior adalah teori tentang perilaku manusia yang dikemukakan oleh Icek Ajzen pada tahun 1985. Teori ini diajukan oleh Icek Ajzen (1988 - 1991) untuk membantu memahami bagaimana kita dapat merubah perilaku seseorang. Teori intensi mengalami perkembangan, dimana pada awalnya hanya berisi mengenai theory of reasoned action (teori tindakan beralasan) yang memiliki dua fungsi determinan, yaitu sikap dan norma subyektif hingga berkembang menjadi planned behavior theory (teori tingkah laku terencana) dengan membentuk tiga fungsi determinan, yaitu sikap terhadap perilaku yang bersangkutan, norma subyektif, dan persepsi kontrol perilaku (Ajzen, 2001).

Teori yang menjelaskan hubungan antara sikap dengan perilaku antara lain adalah Theory of Planned Behavior (TPB) yang merupakan pengembangan dari Theory of Reasoned Action (TRA). Dalam TRA yang diaplikasikan dalam perilaku konsumen, perilaku beli dipengaruhi oleh niat (intention), sikap terhadap perilaku (attitude towards behavior) dan norma-norma subyektif (subjective norm) (Jogiyanto, 2007). TPB merupakan pengembangan dari TRA. TPB mencoba menjelaskan perilaku konsumen yang kompleks yang menbutuhkan kontrol keperilakuan atau kemampuan untuk berperilaku. TPB menjelaskan bahwa niat berperilaku (behavioral intention) tidak hanya dipengaruhi oleh sikap terhadap perilaku (attitude towards behavior) dan norma subyektif (subjective norm), tetapi juga dipengaruhi oleh kontrol keperilakuan yang dirasakan (perceived behavioral control). Kontrol keperilakuan yang dirasakan dipengaruhi oleh pengalaman masa lalu dan perkiraan seseorang mengenai sulit atau tidaknya untuk melakukan perilaku tertentu (Jogiyanto, 2007).

Sikap

Sikap (attitude) adalah evaluasi, perasaan, dan kecenderungan yang konsisten atas suka atau tidak sukanya seseorang atas objek atau ide (Kotler \& Armstrong, 2013). Beberapa ahli manajemen pemesanan mendefinisikan sikap adalah perasaan dari konsumen (positif dan negatif) dari suatu objek setelah dia mengevaluasi objek tersebut. Semakin banyak objek yang dievaluasi akan semakin banyak sikap yang terbentuk. Sikap memiliki beberapa fungsi, yaitu fungsi penyesuaian, ego defensive, ekspresi nilai dan pengetahuan (Oentoro, 2012). Sikap konsumen merupakan suatu respon yang diberikan oleh pesan iklan dan ditangkap oleh konsumen. Sikap terhadap perilaku didefinisikan sebagai perasaan positif atau negatif seseorang jika harus melakukan perilaku yang akan ditentukan, definisi lainnya Sikap sebagai tingkat evaluasi diri saat seseorang merasa menguntungkan atau tidak menguntungkan saat penilaian terhadap perilaku yang dimaksud (Ajzen, 2001).

\section{Norma Subjektif}

Norma subyektif berasal dari teori tindakan beralasan (theory of reasoned action) mengusulkan bahwa intensi/niat berperilaku (behavioral intention) adalah suatu fungsi dari sikap (attitude) dan norma-norma subjektif (subjective norms) terhadap perilaku. Ini berarti intensi/niat seseorang untuk berperilaku (behavioral intention) diprediksi oleh sikapnya terhadap perilakunya (attitude atau lengkapnya attitude towards the behavior) dan bagaimana dia berpikir orang lain akan menilainya jika dia melakukan perilaku itu (disebut dengan norma-norma subjektif). Sikap (attitude) seseorang dikombinasikan dengan norma-norma subjektifnya (subjective norms) akan membentuk intensi/niat perilakunya (Jogiyanto, 2007). Norma subjektif adalah persepsi atau pandangan seseorang terhadap kepercayaan-kepercayaan orang lain yang akan memengaruhi intensi/minat untuk melakukan atau tidak melakukan perilaku yang sedang dipertimbangkan (Jogiyanto, 2007).

\section{Perceived Behavioral Control}

Pendidikan berbeda dengan pelatihan. Pelatihan bersifat spesifik, praktis, dan segera. Yang dimaksud dengan spesifik dalam arti pelatihan berhubungan secara spesifik dengan pekerjaan yang dilakukan. Sedangkan yang dimaksud dengan praktis dan segera adalah bahwa apa yang sudah dilatihkan dapat diaplikasikan dengan segera sehingga yang diberikan harus bersifat praktis (Nasution, 2005). Pelatihan merupakan bagian dari pendidikan. Pendidikan lebih bersifat filosofis dan teoritis. Walaupun demikian, pendidikan dan pelatihan memiliki tujuan yang sama, yaitu pembelajaran. Di dalam pembelajaran terdapat pemahaman secara implisit. Melalui pemahaman, karyawan dimungkinkan untuk menjadi seorang innovator, pengambil inisiatif, pemecah masalah yang Kreatif,serta menjadikan karyawan efektif dan efisien dalam melakukan pekerjaan (Nasution, 2005).

Niat 
Niat atau Intensi (intention) diartikan sebagai niat individu untuk melakukan perilaku didasari oleh sikap terhadap perilaku, norma subyektif, dan persepsi kontrol perilaku (Fitzsimmons \& Brisbane, 2016.). Fishbein (2001) menambahkan intensi perilaku merupakan determinan terdekat dengan perilaku yang dimaksud dan merupakan prediktor tunggal terbaik bagi perilaku yang akan dilakukan. Bandura (Liñán \& Fayolle, 2015), menyatakan intensi adalah satu kebulatan tekad untuk melakukan aktivitas tertentu atau menghasilkan suatu keadaan tertentu dimasa yang akan datang. Beberapa faktor yang mempengaruhi intensi menurut Ajzen (2001), antara lain: 1) Sikap terhadap perilaku adalah penilaian yang bersifat pribadi dari individu yang bersangkutan, menyangkut pengetahuan dan keyakinannya mengenai perilaku tertentu, baik dan buruknya, keuntungan dan manfaat. 2) Norma subyektif terhadap perilaku yang mencerminkan pengaruh sosial, yaitu persepsi individu terhadap tekanan sosial untuk melakukan atau tidak melakukan suatu tingkah laku. 3) Persepsi terhadap kontrol perilaku merupakan penilaian terhadap kemampuan atau ketidakmampuan untuk menampilkan perilaku atau penilaian individu mengenai seberapa mudah atau seberapa sulit untuk menampilkan perilaku.

\section{Penelitian Terdahulu}

Tabel 1.

Mapping Jurnal Penelitian Terdahulu

\begin{tabular}{|c|c|c|c|c|c|c|c|}
\hline No & $\begin{array}{c}\text { Nama } \\
\text { Peneliti/ } \\
\text { Tahun }\end{array}$ & Judul & Tujuan & $\begin{array}{l}\text { Metode } \\
\text { Penelitian }\end{array}$ & $\begin{array}{c}\text { Hasil } \\
\text { Penelitian }\end{array}$ & Persamaan & Perbedaan \\
\hline 1. & $\begin{array}{l}\text { (Kapantouw \& } \\
\text { Mandey, } \\
\text { 2015) }\end{array}$ & \begin{tabular}{lrr} 
PENGARUH & SIKAP, NORMA & \multicolumn{2}{c}{ SUBYEKTIF, } \\
DAN GAYA HIDUP TERHADAP & KEPUTUSAN \\
PEMBELIAN HANDPHONE & ASUS D \\
GAMEZONE COMPUTER & & \\
MEGA MALL MANADO & &
\end{tabular} & $\begin{array}{l}\text { Sikap, norma } \\
\text { subjektif, gaya } \\
\text { hidup, } \\
\text { keputusan } \\
\text { pembelian }\end{array}$ & $\begin{array}{l}\text { Variabel } \\
\text { independen } \\
\text { berpengaruh } \\
\text { terhadap } \\
\text { variabel } \\
\text { dependen }\end{array}$ & $\begin{array}{l}\text { Lokasi } \\
\text { penelitian }\end{array}$ & Variabel & Objek \\
\hline 2 & $\begin{array}{l}\text { (Pantouw, } \\
\text { Pangemanan, } \\
\& \quad \text { Tumiwa, } \\
\text { 2017) }\end{array}$ & $\begin{array}{l}\text { THE INFLUENCE OF CONSUMER'S } \\
\text { PERCEPTION, CONSUMER'S ATTITUDES } \\
\text { THROUGH PURCHASE INTENTION OF } \\
\text { PRIVATE LABEL } \\
\text { PRODUCTS IN INDOMARET MANADO }\end{array}$ & $\begin{array}{l}\text { Persepsi } \\
\text { konsumen, } \\
\text { sikap } \\
\text { konsumen, } \\
\text { intensi } \\
\text { membeli }\end{array}$ & $\begin{array}{l}\text { Variabel } \\
\text { independen } \\
\text { berpengaruh } \\
\text { terhadap } \\
\text { variabel } \\
\text { dependen }\end{array}$ & $\begin{array}{l}\text { Lokasi } \\
\text { penelitian }\end{array}$ & Variabel & Objek \\
\hline 3 & $\begin{array}{l}\text { (Binalay, } \\
\text { Mandey, \& } \\
\text { Mintardjo, } \\
\text { 2016) }\end{array}$ & $\begin{array}{l}\text { PENGARUH SIKAP, NORMA SUBJEKTIF DAN } \\
\text { MOTIVASI TERHADAP MINAT BELI SECARA } \\
\text { ONLINE PADA MAHASISWA FAKULTAS } \\
\text { EKONOMI DAN BISNIS DI MANADO }\end{array}$ & $\begin{array}{l}\text { Sikap, norma } \\
\text { subjektif, } \\
\text { motivasi, } \\
\text { minat beli }\end{array}$ & $\begin{array}{l}\text { Variabel } \\
\text { independen } \\
\text { berpengaruh } \\
\text { terhadap } \\
\text { variabel } \\
\text { dependen }\end{array}$ & $\begin{array}{l}\text { Lokasi } \\
\text { penelitian }\end{array}$ & Variabel & Objek \\
\hline 4 & $\begin{array}{l}\text { (Montjai, } \\
\text { Tewal, \& } \\
\text { Lengkong, } \\
\text { 2014) }\end{array}$ & $\begin{array}{l}\text { MOTIVASI, SIKAP DAN MINAT BELI } \\
\text { KONSMEN PENGARUHNYA TERHADAP } \\
\text { KEPUTUSAN } \\
\text { PEMBELIAN SEPEDA MOTOR YAMAHA PT. } \\
\text { HASJRAT ABADI } \\
\text { SENTRAL YAMAHA MANADO }\end{array}$ & $\begin{array}{l}\text { Motivasi, } \\
\text { sikap, minat } \\
\text { beli, } \\
\text { keputusan } \\
\text { pembelian }\end{array}$ & $\begin{array}{l}\text { Variabel } \\
\text { independen } \\
\text { berpengaruh } \\
\text { terhadap } \\
\text { variabel } \\
\text { dependen }\end{array}$ & $\begin{array}{l}\text { Lokasi } \\
\text { penelitian }\end{array}$ & Variabel & Objek \\
\hline 5 & $\begin{array}{l}\text { (Manoppo, } \\
\text { 2015) }\end{array}$ & $\begin{array}{l}\text { PENGARUH PERSEPSI, SIKAP DAN } \\
\text { MOTIVASI KONSUMEN TERHADAP MINAT } \\
\text { PENGGUNAAN JASA PENGIRIMAN TIKI DI } \\
\text { MANADO }\end{array}$ & $\begin{array}{l}\text { Persepsi, } \\
\text { sikap, } \\
\text { motivasi } \\
\text { konsumen, } \\
\text { minat } \\
\text { penggunaan }\end{array}$ & $\begin{array}{l}\text { Variabel } \\
\text { independen } \\
\text { berpengaruh } \\
\text { terhadap } \\
\text { variabel } \\
\text { dependen }\end{array}$ & $\begin{array}{l}\text { Lokasi } \\
\text { penelitian }\end{array}$ & Variabel & Objek \\
\hline
\end{tabular}




\section{Model Penelitian}

Model penelitian ini dapat dilihat pada Gambar 1 berikut.

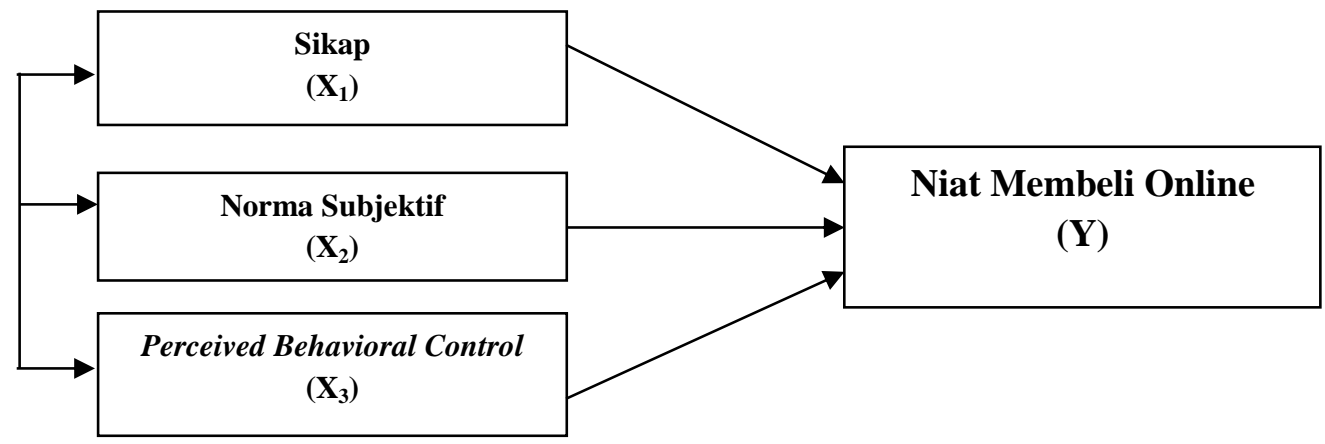

Gambar 1.Model Penelitian

Sumber : Kajian Teori

METODE PENELITIAN

\section{Jenis Penelitian}

Jenis penelitian yang digunakan adalah penelitian kuantitatif. Penelitian ini untuk melihat pengaruh antara variabel Uji penelitian ini termasuk uji asosiasi menggunakan analisis korelasi dan regresi adalah alat analisis yang sering dipakai dalam uji asosiasi penelitian ini merupakan penelitian yang bertujuan untuk mengetahui hubungan dua variabel atau lebih (Sugiyono, 2017).

Waktu dan Lokasi Penelitian

Penelitian dilakukan selama satu bulan di tahun 2017. Penelitian dilakukan di Fakultas Ekonomi dan Bisnis Universitas Sam Ratulangi Manado.

\section{Populasi dan Sampel}

Sugiyono (2017) menyatakan bahwa populasi adalah: "Wilayah generalisai yang terdiri atas: objek/subjek yang mempunyai kualitas dan karakteristik tertentu yang ditetapkan oleh peneliti untuk dipelajari dan ditarik kesimpulannya." Berdasarkan pengertian di atas maka yang menjadi populasi penelitian ini adalah seluruh mahasiswa di FEB Unsrat.

Sugiyono (2017) menyatakan sampel merupakan: "Sampel adalah bagian dari jumlah dan karakteristik yang dimiliki oleh populasi tersebut". Jumlah sampel ditentukan oleh peneliti sebanyak 100 orang responden. Sampel dibagikan sebanyak 100 kuesioner dengan pengambilan sampel insidentil yaitu mahasiswa yang ditemui dijadikan sebagai sampel. Dari hasil kuesioner yang dibagikan hanya sekitar 80 kuesioner yang layak untuk dianalisis lebih lanjut atau $80 \%$ dari total kueioner

\section{Teknik Analisis Data}

Data yang terkumpul akan dianalisis dengan beberapa tahap, pertama uji validitas dan reliabilitas instrumen penelitian, uji asumsi klasik, dan terakhir analisis analisis regresi linear berganda. Data yang diperoleh dari responden lewat kuesioner dikodekan sesuai dengan skala Likert 1 - 5, dan kemudian ditabulasi dengan menggunakan analisis statistik dengan program komputer SPSS.

\section{HASIL PENELITIAN DAN PEMBAHASAN}

\section{Hasil Penelitian}

\section{Uji Validitas dan Reliabilitas}

Pengujian validitas dilakukan dengan mengkorelasikan antara jumlah skor setiap butir soal dengan jumlah skor soal, sedangkan reliabilitas dilakukan dengan menggunakan rumus Cronbach Alpha. Untuk pengujian validitas 
dimana butir soal dianggap valid jika Pearson Correlation lebih besar dari 0.3. Sedangkan dikatakan reliabel jika mempunyai koefisien diatas 0,60 (Sugiyono, 2018). Berdasarkan hasil penelitian korelasi dari masing-masing item terhadap jumlah skor total (corrected item-total correlation) untuk masing-masing indikator dari seluruh variabel baik variabel independen maupun variabel dependen menghasilkan nilai >0,3. Sehingga dapat dikatakan bahwa seluruh item pernyataan untuk variabel keputusan pembelian adalah valid.

Berdasarkan pengujian reliabilitas untuk semua variabel menunjukkan bahwa Cronbach Alpha > 0,6. Hal ini berarti bahwa kusioner yang digunakan untuk mengukur variabel independen dan dependen adalah reliabel.

\section{Analisa Regresi Linier Berganda}

Merujuk pada lampiran dari penelitian ini dimana perhitungan analisis regresi linear berganda dengan bantuan program SPSS seperti pada Tabel 2. berikut ini.

Tabel 2.Regresi Berganda

Coefficients $^{\mathbf{a}}$

\begin{tabular}{|c|c|c|c|c|c|c|c|c|}
\hline \multirow{2}{*}{\multicolumn{2}{|c|}{ Model }} & \multicolumn{4}{|c|}{$\begin{array}{l}\text { Standardized } \\
\text { Coefficients }\end{array}$} & \multirow[b]{2}{*}{ Sig. } & \multicolumn{2}{|c|}{ Collinearity Statistics } \\
\hline & & $\mathrm{B}$ & Std. Error & Beta & $\mathrm{t}$ & & Tolerance & VIF \\
\hline 1 & (Constant) & .649 & 1.379 & & .465 & .003 & & \\
\hline & $\mathrm{X} 1$ & .745 & .132 & .570 & 5.507 & .000 & .264 & 3.783 \\
\hline & $\mathrm{X} 2$ & .189 & .116 & .159 & 1.590 & .006 & .283 & 3.537 \\
\hline & X3 & .336 & .106 & .233 & 3.152 & .002 & .517 & 1.936 \\
\hline
\end{tabular}

a. Dependent Variable: $\mathrm{Y}$

Sumber: Olahan Data (2017)

Berdasarkan Tabel 2, dengan melihat koefisien beta $(\beta)$ untuk masing-masing variabel maka persamaan regresi ganda yang dihasilkan adalah sebagai berikut :

$\mathrm{Y}=0,649+0,745 \mathrm{X}_{1}+0,189 \mathrm{X}_{2}+0,336 \mathrm{X}_{3}$

Dari persamaan regresi berganda di atas, dapat mengindikasikan: $a=0,649$ adalah bilangan konstanta yang berarti apabila variabel bebas yaitu $X_{1}, X_{2}$ dan $X_{3}$ sama dengan nol, maka niat membeli online adalah 0,649. Koefisien $b_{1}=0,745$ adalah besarnya koefisien regresi $X_{1}$ sikap, yang berarti bahwa setiap peningkatan sikap akan meningkatkan niat membeli online sebesar 0,745 dengan asumsi variabel lainnya yang diteliti adalah konstan. Koefisien $b_{2}=0,189$ adalah besarnya koefisien regresi X2 atau norma subyektif yang berarti setiap peningkatan norma subyektif akan meningkatkan niat membeli online sebesar 0,189 dengan asumsi variabel lain dalam penelitian ini adalah konstan. Koefisien $\mathrm{b}_{3}=0,336$ adalah besarnya koefisien regresi $\mathrm{X}_{3}$ atau perceived behavioral control, yang berarti bahwa setiap peningkatan ini akan meningkatkan niat membeli online sebesar 0,336 dengan asumsi variabel lainnya yang diteliti adalah konstan.

\section{Uji Hipotesis Secara Parsial (Uji t)}

Berdasarkan hasil perhitungan yang dapat dilihat pada tabel 2 diperoleh nilai signifikansi (sig.) t untuk sikap adalah sebesar 0,000 lebih kecil dari 0,05. Dengan demikian maka hipotesis nul $\left(\mathrm{H}_{\mathrm{o}}\right)$ ditolak; sekaligus menerima hipotesis alternatif $\left(\mathrm{H}_{\mathrm{a}}\right)$ yang menyatakan bahwa sikap (X1) berpengaruh terhadap niat membeli online. Dengan diterimanya hipotesis alternatif ini maka dengan demikian maka hipotesis 2 yang menyatakan bahwa Ada pengaruh sikap terhadap niat membeli online adalah terbukti.

Berdasarkan hasil perhitungan yang dapat dilihat pada tabel 2 diperoleh nilai signifikansi (sig.) t untuk norma subjektif adalah sebesar 0,006 lebih kecil dari 0,05. Dengan demikian maka hipotesis nul $\left(\mathrm{H}_{\mathrm{o}}\right)$ ditolak; sekaligus menerima hipotesis alternatif $\left(\mathrm{H}_{\mathrm{a}}\right)$ yang menyatakan bahwa norma subjektif (X2) berpengaruh terhadap niat membeli online. Dengan diterimanya hipotesis alternatif ini maka dengan demikian maka hipotesis 3 yang menyatakan bahwa Ada pengaruh norma subjektif terhadap niat membeli online adalah terbukti.

Berdasarkan hasil perhitungan yang dapat dilihat pada tabel 2 diperoleh nilai signifikansi (sig.) t untuk perceived behavioral control adalah sebesar 0,002 lebih kecil dari 0,05. Dengan demikian maka hipotesis nul $\left(\mathrm{H}_{\mathrm{o}}\right)$ ditolak; sekaligus menerima hipotesis alternatif $\left(\mathrm{H}_{\mathrm{a}}\right)$ yang menyatakan bahwa perceived behavioral control (X3) 
berpengaruh terhadap niat membeli online. Dengan diterimanya hipotesis alternatif ini maka dengan demikian maka hipotesis 4 yang menyatakan bahwa Ada pengaruh perceived behavioral control terhadap niat membeli online adalah terbukti.

Uji Hipotesis Secara Simultan (Uji F)

Tabel 3 Anova

ANOVA $^{\mathrm{a}}$

\begin{tabular}{lllllll}
\hline Model & & Sum of Squares & df & Mean Square & F & Sig. \\
\hline 1 & Regression & 651.826 & 3 & 216.647 & 95.532 & $.000^{\mathrm{b}}$ \\
& Residual & 178.935 & 76 & 2.341 & & \\
& Total & 837.898 & 79 & & & \\
\hline
\end{tabular}

a. Dependent Variable: $\mathrm{Y}$

b. Predictors: (Constant), X3, X1, X2

Sumber: Olahan Data (2017)

Berdasarkan Tabel 3 dapat dilihat bahwa angka $F$ sebesar 95,532 dengan tingkat signifikan sebesar 0,000< 0.05. Dengan demikian maka hipotesis nul $\left(\mathrm{H}_{\mathrm{o}}\right)$ yang menyatakan bahwa sikap, norma subjektif, dan perceived behavioral control tidak berpengaruh terhadap niat membeli online adalah ditolak; sekaligus menerima hipotesis alternatif $\left(\mathrm{H}_{\mathrm{a}}\right)$ yang menyatakan sikap, norma subjektif, dan perceived behavioral control berpengaruh terhadap niat membeli online. Dengan diterimanya hipotesis alternatif ini maka dengan demikian maka hipotesis 1 yang menyatakan bahwa Ada pengaruh sikap, norma subjektif, dan perceived behavioral control terhadap niat membeli online adalah terbukti.

\section{Koefisien Korelasi}

Pada Tabel 4 berikut merupakan Tabel model summary untuk mengetahui koefisien korelasi berganda.

Tabel 4 Model Summary

Model Summary

\begin{tabular}{llllll}
\hline & & & & Std. Error & of \\
Model & $\mathrm{R}$ & R Square & Adjusted R Square & Estimate & Durbin-Watson \\
\hline 1 & $.888^{\mathrm{a}}$ & .775 & .769 & 1.531 & 1.425 \\
\hline
\end{tabular}

a. Predictors: (Constant), X3, X1, X2

b. Dependent Variable: Y

Sumber: Olahan Data (2017)

Tabel 4 ringkasan model (model summary) dapat dilihat besarnya koefisien korelasi ganda (r) dari model hubungan antara sikap, norma subyektif, dan perceived behavioral control terhadap niat membeli online adalah sebesar 0,888. Dengan demikian maka pengaruh antara sikap, norma subyektif, dan perceived behavioral control terhadap niat membeli online adalah kuat.

Untuk melihat besarnya kontribusi dari sikap, norma subyektif, dan perceived behavioral control terhadap niat membeli online ditunjukkan oleh besarnya angka koefisien determinasi $\left(r^{2}\right)$ sebesar 0,775. Angka ini menunjukkan besarnya kontribusi dari variabel-variabel sikap, norma subyektif, dan perceived behavioral control terhadap niat membeli online adalah sebesar 77,5\% sedangkan sisanya sebesar 0,225 atau 22,5\% disebabkan oleh variabel lainnya yang tidak diteliti dalam penelitian ini.

\section{Pembahasan}

Berdasarkan Uji Statistik dapat dijelaskan bahwa sikap, norma subyektif, dan perceived behavioral control berpengaruh secara bersama-sama atau secara parsial berpengaruh terhadap niat membeli online pada UKM di Manado dengan nilai koefisien yang positif dan signifikan. Berdasarkan hasil uji statistik dapat dijelaskan bahwa niat membeli online pada UKM di Manado dipengaruh oleh variabel-variabel seperti sikap, norma subyektif, dan perceived behavioral control, meskipun dalam model ini juga mengindikasikan adanya pengaruh dari variabelvariabel lain yang tidak diteliti dalam penelitian ini. Namun hasil penelitian menunjukkan bahwa model yang 
dikembangkan yaitu pengaruh antara sikap, norma subyektif, dan perceived behavioral control terhadap niat membeli online adalah cocok (fit) karena hasilnya positif dan signifikan.

Berdasarkan Uji Statistik secara parsial dapat dijelaskan bahwa sikap, norma subjektif dan perceived behavioral control berpengaruh terhadap niat membeli online pada UKM di Manado. dengan nilai koefisien yang semuanya posiif dan signifikan. Hasil ini mengindikasikan variabel sikap, norma subjektif serta perceived behavioral control dapat memprediksi peningkatan atau penurunan niat membeli online di usaha kecil dan menengah khususnya di daerah Manado.

\section{Keterbatasan Penelitian}

Keterbatasan penelitian ini yaitu:

1. Penelitian hanya terbatas di wilayah Manado saja serta subjek penelitian terbatas pada mahasiswa perguruan tinggi.

2. Variabel yang dipakai sebagai prediktor bagi niat membeli online perlu ditambah atau disesuaikan dengan variabel-variabel lainnya yang dianggap paling dominan berpengaruh.

3. Keterbatasan dana dan waktu serta sumber daya lainnya menyebabkan penelitian ini hanya dibatasi pada variabel serta objek penelitian yang telah ditetapkan sebelumnya.

\section{PENUTUP}

\section{Kesimpulan}

Kesimpulan penelitian ini adalah :

1. Berdasarkan hasil uji hipotesis khususnya model penelitian ditemukan bahwa sikap, norma subyektif serta perceived behavioral control secara bersama-sama atau simultan dalam satu model penelitian memiliki pengaruh yang positif dan signifikan terhadap niat membeli online pada UKM di Manado.

2. Berdasarkan hasil uji hipotesis ditemukan bahwa secara parsial atau individual variabel sikap memiliki pengaruh yang positif dan signifikan terhadap niat membeli online pada UKM di Manado. Variabel ini merupakan variabel yang paling dominan pengaruhnya terhadap niat membeli online.

3. Berdasarkan hasil uji hipotesis ditemukan bahwa secara parsial atau individual variabel norma subjektif memiliki pengaruh yang positif dan signifikan terhadap niat membeli online pada UKM di Manado. Variabel ini merupakan variabel yang paling kecil pengaruhnya terhadap niat membeli online dibandingkan dua variabel lainnya.

4. Berdasarkan hasil uji hipotesis ditemukan bahwa secara parsial atau individual variabel perceived behavioral control memiliki pengaruh yang positif dan signifikan terhadap niat membeli online pada UKM di Manado. Variabel ini merupakan variabel kedua terkuat yang berpengaruh terhadap niat membeli online

\section{Saran}

Saran yang dapat diberikan adalah

1. UKM di Manado yang fokus pada penjualan online perlu memperhatikan hasil temuan penelitian ini. Variabelvariabel sikap, norma subjektif dan perceived behavioral control harus diimplementasikan dan terus ditingkatkan untuk meningkatkan niat membeli online dari para konsumen.

2. Hasil penelitian ini dapat digunakan untuk pengembangan ilmu manajemen pemasaran terkait dengan niat membeli secara online.

3. Perlu ada penelitian replikasi dari penelitian ini untuk diterapkan pada lokasi ataupun objek penelitian lainnya. 


\section{DAFTAR PUSTAKA}

Ajzen, I. (2001). Nature and Operation of Attitudes. Annual Review of Psychology, 52, 27-58.

Binalay, A. G., Mandey, S. L., \& Mintardjo, C. M. O. (2016). PENGARUH SIKAP, NORMA SUBJEKTIF DAN MOTIVASI TERHADAP MINAT BELI SECARA ONLINE PADA MAHASISWA FAKULTAS EKONOMI DAN BISNIS DI MANADO. Jurnal EMBA, 4(1), 395-406.

Fitzsimmons, J., \& Brisbane, G. S. (2016). ENTREPRENEURIAL ATTITUDES AND ENTREPRENEURIAL INTENTIONS: A CROSS-CULTURAL STUDY OF POTENTIAL ENTREPRENEURS IN INDIA, CHINA, THAILAND AND AUSTRALIA., 20.

Jogiyanto, H. (2007). Metodologi Penelitian Sistem Informasi. Yogyakarta: ANDI.

Kapantouw, C., \& Mandey, S. L. (2015). PENGARUH SIKAP, NORMA SUBYEKTIF, DAN GAYA HIDUP TERHADAP KEPUTUSAN PEMBELIAN HANDPHONE ASUS DI GAMEZONE COMPUTER MEGA MALL MANADO. Jurnal EMBA, 3(2), 706-718.

Kotler, P., \& Armstrong, G. (2013). Dasar-Dasar Pemasaran. Jakarta: Penerbit Indeks.

Kotler, P., \& Keller, K. L. (2009). Manajemen Pemasaran (12 ed.). Jakarta: Indeks.

Liñán, F., \& Fayolle, A. (2015). A systematic literature review on entrepreneurial intentions: citation, thematic analyses, and research agenda. International Entrepreneurship and Management Journal, 11(4), 907-933. https://doi.org/10.1007/s11365-015-0356-5

Liputan6.com. (2017, Agustus 14). 2018, Transaksi e-Commerce Indonesia Akan Capai Rp 144 Triliun. Diambil 24 Agustus 2018, dari https://www.liputan6.com/tekno/read/3057134/2018-transaksi-e-commerce-indonesia-akancapai-rp-144-triliun

Liputan6.com. (2017, Mei 20). Pertumbuhan e-Commerce Indonesia Tertinggi di Dunia. Diambil 24 Agustus 2018, dari https://www.liputan6.com/tekno/read/2957050/pertumbuhan-e-commerce-indonesia-tertinggi-di-dunia

Manoppo, M. C. (2015). PENGARUH PERSEPSI, SIKAP DAN MOTIVASI KONSUMEN TERHADAP MINAT PENGGUNAAN JASA PENGIRIMAN TIKI DI MANADO. Jurnal EMBA, 3(1), 266-276.

Montjai, O., Tewal, B., \& Lengkong, V. P. K. (2014). MOTIVASI, SIKAP DAN MINAT BELI KONSMEN PENGARUHNYA TERHADAP KEPUTUSAN PEMBELIAN SEPEDA MOTOR YAMAHA PT. HASJRAT ABADI SENTRAL YAMAHA MANADO. Jurnal EMBA, 2(4), 35-45.

Oentoro, D. (2012). Manajemen Pemasaran Modern. Yogyakarta: Laksbang Pressindo. 
Pantouw, E. J., Pangemanan, S., \& Tumiwa, J. (2017). THE INFLUENCE OF CONSUMER'S PERCEPTION, CONSUMER'S ATTITUDES THROUGH PURCHASE INTENTION OF PRIVATE LABEL PRODUCTS IN INDOMARET MANADO. Jurnal EMBA, 5(2), 2417-2425.

Sugiyono. (2017). Metode Penelitian Bisnis: Pendekatan Kuantitatif, Kualitatif, Kombinasi, dan R\&D. Bandung: Alfabeta.

Sugiyono. (2018). Metode Penelitian Kuantitatif. Bandung: Alfabeta. 